\title{
Chapter 8 \\ Functions and Success Conditions of Student Feedback in the Development of Teaching and Teachers
}

\author{
Benedikt Wisniewski and Klaus Zierer
}

\begin{abstract}
The term "student feedback" is often used synonymously with evaluation, assessment, or ratings of teaching, but can be conceptually delimitated from these concepts, distinguishing formative and summative aspects. Obtaining feedback is a core component of teachers' professional development. It is the basis for critical self-reflection, a prerequisite of reducing discrepancies between one's performance and set goals, a tool to identify blind spots, and a means of correcting false selfassessments. Student feedback opens up opportunities for teachers to improve on their teaching by comparing students' perspectives on instructional quality to their own perspectives. Feedback can also help teachers to implement democratic principles, and experience self-efficacy. Conditions are discussed that need to be fulfilled for student feedback to be successful.
\end{abstract}

Keywords Student feedback · Professional development - Democratization • Teacher satisfaction

\section{Introduction}

Student feedback is a fundamental part of professional teaching practice. In contrast to forms of organizational assessment such as teacher evaluations, which always serve an allocation or selection purpose (e.g. promotion, access to functional positions), feedback has the aim of personal professional development. This development requires a critical reflection that compares one's own experiences with external information, and students can provide this information in a reliable and valid way.

Among wide media interest, two attempts (in 2017 and 2019) were made in Germany and Austria to create online platforms that allowed students to rate their teachers publicly. These platforms (spickmich.de and lernsieg.de) both claimed to

B. Wisniewski $(\bowtie) \cdot \mathrm{K}$. Zierer

Faculty of Philosophy and Social Sciences, University of Augsburg, Augsburg, Germany

e-mail: benedikt.wisniewski@phil.uni-augsburg.de

K. Zierer

e-mail: klaus.zierer@phil.uni-augsburg.de 
provide feedback for teachers in order to improve teaching. By means of categories such as "professional competence", "motivation", "popularity", "clothing", "fair examinations", or "physical appearance", teachers could be evaluated anonymously with grades. After a certain number of ratings per teacher, the results were then made publicly accessible. Due to several complaints by rated teachers and by teachers' unions, both platforms were turned off.

What both platforms had in common were partly irrelevant evaluation criteria (e.g., clothing), evaluation criteria that included areas which could not be (sufficiently) assessed by students (e.g., professional competence), and-as the most critical aspect - a publication of the results.

Starting with these two negative examples, we will show how the functions of student feedback can be defined in a professional context: After a conceptual delimitation, we will point out why feedback is important for the professional development of teachers in general. After that, we will discuss three basic functions of student feedback: the development of teaching, the democratization of schools, and the improvement of teachers' satisfaction and health. In the last step, we will-in brief-propose success conditions of student feedback.

\section{Feedback, Evaluation, Assessment, and Rating-A Conceptual Delimitation}

Because grading plays a central role in most school systems around the world and teachers usually provide feedback in the form of grades, student feedback is often equated with grading teachers (Elstad et al., 2017). The terms "student feedback", "student assessments", "student ratings", and "student evaluations" are used many times in a more or less synonymous way. It is assumed that students grade their teachers-similar to how teachers grade their students. Feedback is considered primarily a summative form of evaluation, rather than a formative form of providing information for professional development. Consequently, parallels are drawn between student feedback in school and student evaluations of teaching at university, the latter of which are widely used for selecting and promoting academic staff. The problems with evaluations of teaching in higher education have been discussed by Sproule (2000, 2002), who argues that the adoption of the "consumer" model of education does not capture the pedagogical process in its entirety, overlooking the students' influence on this process, and that false consequences are drawn from SETs. Research in the higher education context also shows no or only minimal correlation between SET and learning outcomes (Uttl et al., 2017, see Chap. 15 of this volume). Of course, findings like these could be used as arguments against student feedback, but the conceptual blur resulting from different concepts requires a delimitation of what feedback means, what distinguishes it from evaluation, assessment, and ratings (Table 1), and then to define what student feedback really means when we talk about its functions. 
Table 1 Conceptual delimitation (Zierer \& Wisniewski, 2018)

\begin{tabular}{l|l}
\hline Feedback & $\begin{array}{l}\text { Data-based exchange of information between people aimed at development and } \\
\text { serving to adapt one's own behavior in response to feedback from others. }\end{array}$ \\
\hline Evaluation & $\begin{array}{l}\text { Investigation of whether and to what extent a behavior is suitable for achieving a } \\
\text { desired target state or fulfilling a purpose. }\end{array}$ \\
\hline Assessment & $\begin{array}{l}\text { Verification of the extent to which a person's behavior or qualities are consistent } \\
\text { with the evaluators' standards, usually expressed in terms of statements such as } \\
\text { "good" or "bad". }\end{array}$ \\
\hline Rating & $\begin{array}{l}\text { Measures of personal characteristics, performance, and social behavior, usually } \\
\text { expressed in terms of predicates, e.g., in the form of grades. }\end{array}$ \\
\hline
\end{tabular}

A delimitation is of great importance for further discourse on this subject. Student feedback in schools is not synonymous to student evaluations of teaching or student ratings (concepts primarily used in higher education). Basically, and primarily, it provides information for the teachers who obtain it in order to get an impression of how their students experience their teaching. However, studies show that-just like in the higher education context (Marsh \& Dunkin, 1992)—student feedback in schools is very often used for evaluation and assessment purposes rather than as an opportunity for personal change (Elstad et al., 2017) and that instruments are used which do not do justice to the actual purpose, for example by being inappropriate for innovative forms of teaching (Kember et al., 2002). When feedback is used at the end of a term, students believe that their feedback to teachers does not change anything in the classroom (Chen \& Hoshower, 2003; Spencer \& Schmelkin, 2002). When evaluation rather than professional development is emphasized, teachers see student feedback as a controlling tool (Harvey, 2002; Newton, 2000). The formative and summative components of feedback are not categorically incompatible, but an over-emphasis of the summative components can undermine the use of feedback and negatively affect school climate (Ford et al., 2018).

In the following, we will focus on functions of student feedback in schools obtained by teachers in order to acquire information on how students perceive teaching in a formative sense and neglect a more detailed discussion of summative functions used by school administrations to select or promote teachers.

\section{Why Student Feedback Is Important}

The explanation and prediction of the feeling of professional success and professional satisfaction of teachers are often attributed to largely unchangeable and unlearnable personality traits. This attribution is evident in both beginners and experienced teachers (Bromme \& Haag, 2004). If one holds the view that stable personality traits are largely responsible for one's professional success, feedback is mostly irrelevant. However, empirical research shows that the concept of "the born teacher" is 
outdated. It is not the unchangeable characteristics that primarily influence the quality of teaching but rather professional skills and knowledge, motivation, self-regulation, and attitudes (Zierer, 2015). All these are qualities to work on that require constant reflection based on data.

Feedback contains an oral or written external perception after a data collection, whereby these data can be in the micro range as sensory impressions or perceptions of a counterpart (for example the perception of facial expressions and gestures), and in the macro range of an observer in the form of multi-perspective data collection with differentiated methods and instruments, for example, feedback questionnaires (Buhren, 2015). Increasingly, teachers are confronted with the expectation of being reflective practitioners (Schön, 1987) who can develop their professional skills throughout their professional lives (Staub, 2001). There are numerous, partly very different, definitions of professional development (Reh, 2004), but, despite differently substantiated theoretical concepts, a large consensus can be established that reflexivity is a core area of professionalism (ibid.). A (self-)critical reflection that uses both one's own experience and external information forms the core of pedagogical professionalism (Paseka et al., 2011). For this reason, obtaining feedback is a core component of teachers' professional development. As active directors of instruction, they have a very high impact on their students' achievement (Hattie, 2009). However, not all teachers have the same influence. It is particularly high when they try to see teaching through the eyes of their students, when they try to understand how their teaching impacts the learners (ibid.).

According to control theory (Carver \& Scheier, 1982), people constantly compare their performance to a behavioral goal and, when they detect a discrepancy, attempt to reduce this discrepancy. Feedback is a necessary prerequisite of professional reflection, increasing the awareness of behaviors and the impact of these behaviors. It helps to question automatic processes, habits, and routines, providing opportunities for behavioral change. Additionally, feedback influences motivational processes by reducing negative emotions caused by an observed discrepancy between goals and performance and fostering positive emotions by decreasing such a discrepancy (Deci et al., 1999). Furthermore, performers do better on tasks for which higher quality feedback is available (Northcraft et al., 2011).

When teachers state that they do not need feedback because they know best how effective their teaching is, it must be noted that the self-assessment of one's own competences is often wrong. This can generally be proven for different tasks and requirements (Kruger \& Dunning, 1999). In the worst case, the consequence is that students become bored in class, learn less than they could, and the teacher still assumes that he or she is offering the best possible instruction. Feedback serves to prevent such misjudgments by providing information that is only accessible through an external perspective (Wisniewski \& Zierer, 2019).

Feedback is an essential prerequisite for goal-oriented and self-reflective processes because teachers, like any other professional group, have so-called "blind spots" in their professional practice, as described in the model of the Johari window 


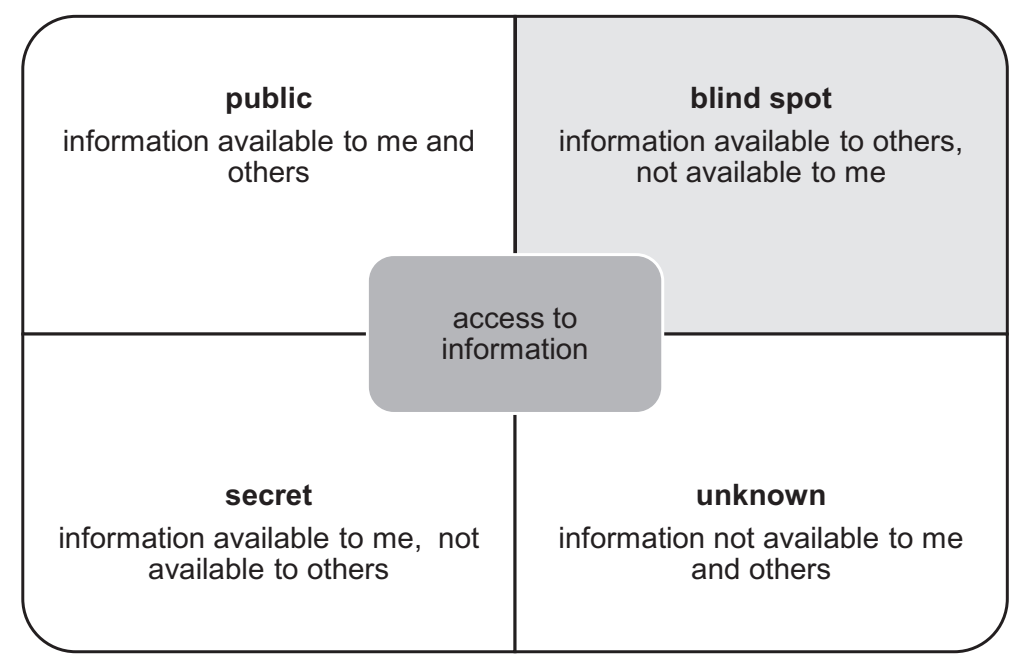

Fig. 1 Johari window for corporate settings (Luft \& Ingham, 1955)

(Luft \& Ingham, 1955, see Fig. 1), a model developed for corporate settings. Like in any other professional context, there is certain relevant information for teachers that is not accessible to a person him or herself but only accessible to others. The relevance of blind spots can range from minor to major-from the frequent repetition of a certain filler word and unfavorable non-verbal signals to the fact that a teacher explains content too quickly or too incomprehensibly (Wisniewski \& Zierer, 2019). The only way to gain access to such blind spots is feedback.

A classic blind spot of teachers is, for example, their estimation of their own speaking time in class. Thus, Helmke and colleagues (2008) were able to show that teachers' estimation of their speaking time during a lesson differs considerably from the time objectively measured. In short: Teachers talk way more than they think they do (Fig. 2). The example shows that there are highly relevant characteristics of teaching that are not accessible through pure self-reflection but need to be communicated from an external perspective.

In this sense, feedback offers the opportunity to reveal blind spots by comparing perspectives. Blind spots can refer to critical aspects of behavior (like in the presented example), but also to strengths and resources that a teacher does not perceive from his or her own perspective. Student feedback can provide teachers with information on both, unknown strengths and unknown weaknesses. 


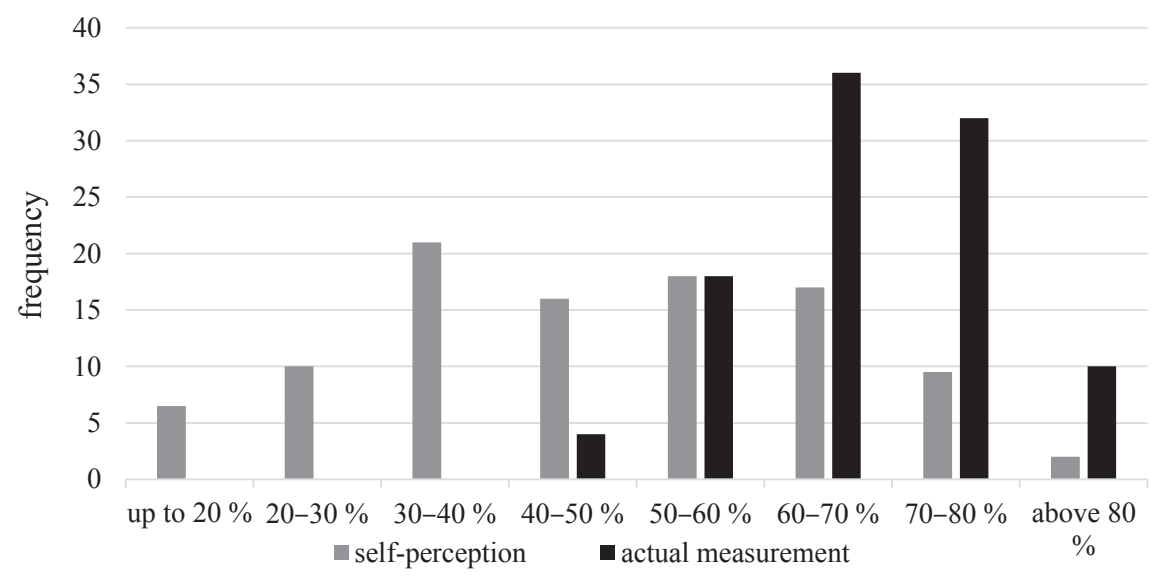

Fig. 2 Speaking time by teachers in the classroom-estimation and actual measurement (Helmke et al., 2008, p. 139)

\section{Developing Teaching and Teachers with Student Feedback}

\subsection{Development of Teaching}

What teachers actually do in their classrooms is one of the strongest predictors of students' learning outcomes (Hattie, 2009; Helmke, 2017; Seidel \& Shavelson, 2007). Consequently, it is crucial to pinpoint what works in the classroom. Student feedback is supposed to help teachers improve the quality of teaching (Ditton \& Arnoldt, 2004; Gärtner, 2007, 2013; Helmke, 2017) by providing diagnostic information on teaching characteristics that determine if students feel sufficiently challenged, engaged, and comfortable asking for help, telling teachers where they need to focus so that their current students benefit, suggest students' misunderstandings, and diagnose teachers' specific attempts at clarification (Gates Foundation, 2012).

Theoretically, improvements of teaching quality by student feedback can be explained in three ways: Firstly, feedback helps teachers to gain information about relevant lesson characteristics that are not accessible through pure self-reflection. Procedures that question learners consciously and directly about the core components of teaching provide opportunities for developing instructional quality. Kunter and Voss (2013) distinguish surface structures (characteristics that are directly observable, e.g., social forms, forms of teaching, methods, media use) from deep structures of teaching (characteristics that become visible through the interpretation of the teaching-learning process, and classroom interaction). Effectiveness of teaching depends largely on the latter (Hattie, 2009) and student feedback is a relatively reliable and valid information source on deep structures (Wisniewski et al., 2020a; see Chap. 7 of Göllner et al. in this volume). They can reveal if one teaching method 
produces better learning results than another, if assignments were clear and produced the intended effect, if students felt comfortable and challenged, if content was properly consolidated, if learning time was used efficiently, if students were able to work without disturbance, if the feedback which students got from the teacher was helpful, and so on. Teachers get an impression which of these aspects were seen critical, but also which of them were perceived favorably by students. It is becoming apparent that positive feedback leads to a further strengthening of the methods that have been successfully used in class, and effects can be seen in the tendency to make teaching more transparent and to regularly reflect on the lessons with the pupils (Gärtner, 2013). Ideally, comparing the student perspective to the teacher perspective and subsequent discussion leads to conclusions on how to optimize teaching (Desimone, 2009). This allows a shift of focus from surface structures of teaching and formal specifications (Have all curriculum goals been achieved?) to actual learning processes that have (or have not) happened in the classroom and helps to answer the question why this was the case.

There can be an action-guiding function of feedback: People, in general, act differently, when they expect feedback (Carver \& Scheier, 1990). Feedback increases general self-awareness, and-consecutively-increases an individual's capability to inhibit behaviors that are undesired or dysfunctional (Alberts et al., 2011). When teachers know that they will get feedback based on certain criteria, they are likely to pay particular attention to these criteria (a reason why valid criteria for student feedback are crucial, see Chap. 4 of this volume). Assessing expectancies before getting feedback can already cause behavioral change. For example, a teacher who expects to get feedback about clarity will most probably be more aware of this aspect and put more emphasis on clarifying than without the expectancy. Similarly, a teacher who expects feedback on classroom management will monitor student behavior more carefully than without the expectancy.

Thirdly, feedback can help to implement innovations in teaching. Professional development aims to achieve change with regard to teachers' attitudes, beliefs, and perceptions that will result in improved student achievement or other desired outcomes. It has been shown by research that changing teachers' attitudes, beliefs, or perceptions requires the experience of successful implementation (Guskey, 2002). Thus, student feedback is one key element in the implementation process, being able to demonstrate that an innovation works (or doesn't work). Student feedback was found to increase implementation of innovations (Mortenson \& Witt, 1998; Noell et al., 2002), providing information on whether innovations have a positive effect.

\subsection{Democratization of Schools}

The development of teaching is often focused on effectiveness, aiming at an increase in student achievement. Student feedback can contribute to the development of teaching in an additional way by promoting democratic attitudes. Feedback between the participants of school life is a basic condition for participation and therefore the 
experience of democratic structures. While professional feedback from teachers to students is the basis for an appreciative climate and successful teacher-student relationships, student feedback is the basic form of freedom of expression with regard to successful learning conditions and the prerequisite for a dialogue about teaching and learning (Wisniewski et al., 2019).

School has an indirect or latent influence on the political socialization of pupils in the sense of the social-cognitive learning theory. A prerequisite for successful interaction is the granting of mutual recognition and appreciation, not as a sufficient, but at least as a necessary condition for a democratic form of school life. "When developing a political standpoint, young people apparently pay less attention to bold confessions and teachings than to the nuances both in interpersonal relationships and in the context of educational institutions" (Kleeberg-Niepage, 2012, p. 13, translated). The participation of young people in discussions and co-determination processes in educational institutions plays an important role (see Chap. 13 of this volume).

Student feedback contains several components of a basic understanding of democracy: Students are given the opportunity to express their opinions in a differentiated way. They have to think about how different criteria for the quality of teaching are to be assessed in each individual case instead of assessing teaching in general as "great" or "bad". They realize that their own opinion is not to be seen as absolute, but that there are different perspectives on a subject. They learn to engage in a dialogue with their teachers on how changes can lead to better conditions for all those involved and thus influence an area relevant to them-nothing other than social participation in the school system. And finally, feedback offers the opportunity for mutual appreciation between teachers and learners.

\subsection{Improving Teachers' Satisfaction and Health}

Student feedback can help to improve teaching, but an additional-and often overlooked - potential benefit it provides is teachers' development of a professional experience that is more satisfactory, and - as a consequence-healthier. Although, this may seem contra-intuitional because feedback can (and often does) include criticism, research suggests a cautious assumption of such positive effects.

Teachers' satisfaction is a key affective reaction to working conditions and an important predictor of teacher attrition (Ford et al., 2018). It is related to their expectations of self-efficacy, in other words the belief that they can produce desirable changes in student achievement (Ford et al., 2018; Skaalvik \& Skaalvik, 2007; Wang et al., 2015), which in turn is enhanced by feedback. Teachers with low self-efficacy expectations do not believe that they can successfully provide instruction that will increase student performance (Finnegan, 2013), whereas teachers who experience that their use of feedback leads to positive changes in their practice have higher satisfaction than those who don't (Ford et al., 2018). When teachers are given areas to improve or reflect on, their perception of the effectiveness is higher than when only praise is given (Milanowski \& Heneman, 2001). 
Enns and colleagues (2002) have been able to demonstrate that teachers who seek regular feedback in their professional practice

- have the feeling of being encouraged as teachers,

- gain in perceived safety,

- put their own weaknesses into perspective,

- establish working partnerships,

- establish a research-oriented attitude in the classroom,

- develop openness and sensitivity,

- increase their job satisfaction,

- reduce stress factors,

- experience self-efficacy, and

- benefit from recognition.

In this sense, feedback does not-as one might expect-demotivate teachers by criticism, but, contrary to this, support and encourage them. Feedback even has this motivating effect, regardless of whether it is positive or negative (Pritchard et al., 2002). Further, it leads to a more realistic self-assessment (Mayo et al., 2012), promotes a solution-oriented approach to problems (Enns et al., 2002), and increases the experience of self-efficacy. Considering this, the reflection on lessons with the help of external data can be one of the most important resources for satisfactory professional practice.

Finally, job satisfaction has an effect on teachers' health. Symptoms of burnout (emotional exhaustion and depersonalization) are negatively related to teacher selfefficacy (Skaalvik \& Skaalvik, 2007) and teachers with a high sense of efficacy seem to employ a pattern of strategies that minimized negative emotions (Finnegan, 2013). It is at least plausible that an increase in the above-mentioned areas will in turn have a positive effect on the quality of teaching. Reciprocally, students give more positive feedback to teachers who-in the sense of a low psychosocial risk for stress symptoms - show a favorable combination of work commitment, resilience and emotions, a high degree of resistance to professional problems, and a higher level of positive emotions (Klusmann et al., 2006). Consequently, student feedback can make a significant contribution not only to job satisfaction, but to the health of teachers.

\section{Success Conditions of Student Feedback}

We have tried to show in this chapter that student feedback has a number of important functions for the development of teaching and teachers. However, there are several success conditions that are a prerequisite for student for feedback to be able to really fulfill these functions. Therefore, we propose the following four criteria:

1. The aim of student feedback needs to be transparent to all participants. 
Formative student feedback with the purpose of personal development must be clearly separated from any forms of summative evaluations, assessments, or ratings that are used for administrative decisions. Transparency is also needed with regard to the availability of feedback results: the obtaining teacher should be able to decide who has access to these results.

2. Student feedback needs to be informative.

Feedback is most useful when it contains a high amount of information (Hattie \& Timperley, 2007; Wisniewski et al., 2020b). Consequently, student feedback should provide information that allows the teacher to gain detailed insight into strengths and weaknesses of her or his teaching, pointing at opportunities to make suitable changes and reinforcing functional behavior.

3. Student feedback needs to be based on sound criteria.

In many schools, ad hoc instruments that are mainly based on everyday assumptions and not on sound theory are used to obtain student feedback (Ory \& Ryan, 2001). This brings the disadvantage that criteria are highly subjective and arbitrary. Useful student feedback is based on criteria whose importance is supported by empirical evidence and which cover deep structures of teaching (with positive effects on student learning).

4. Teachers need support when dealing with student feedback.

The most crucial step in the process of using student feedback is not obtaining information but dealing with the information. Penny and Coe (2004) have shown the importance of supporting teachers when dealing with feedback information. High impact was found when teachers had various support systems at hand, including counseling and coaching.

\section{Conclusion}

The various functions of student feedback suggest that it is a self-evident part of teachers' professional development, providing valuable information with no or low cost. It is therefore rather astonishing, that it is still not a matter of course in schools. Student feedback helps to get into conversation about teaching and learning. Sometimes this is the beginning of a real feedback culture. 


\section{References}

Alberts, H. J., Martijn, C., \& de Vries, N. K. (2011). Fighting self-control failure: Overcoming ego depletion by increasing self-awareness. Journal of Experimental Social Psychology, 47(1), 58-62. https://doi.org/10.1016/j.jesp.2010.08.004.

Bromme, R., \& Haag, L. (2004). Forschung zur Lehrerpersönlichkeit [Research on teacher personality]. In W. Helsper \& J. Böhme (Eds.), Handbuch der Schulforschung [Manual of school research] (pp. 777-794). VS Verlag. https://doi.org/10.1007/978-3-663-10249-6_31.

Buhren, C. G. (2015). Feedback-Definitionen und Differenzierungen [Feedback definitions and differentiations]. In ibid. (Ed.), Handbuch Feedback in der Schule [Manual on feedback in schools] (pp. 11-30). Beltz. https://doi.org/10.1007/978-3-658-10223-4_2.

Carver, C. S., \& Scheier, M. F. (1982). Control theory: A useful conceptual framework for personality-social, clinical, and health psychology. Psychological Bulletin, 92(1), 111-135. https://doi. org/10.1037/0033-2909.92.1.111.

Carver, C. S., \& Scheier, M. F. (1990). Origins and functions of positive and negative affect: A control-process view. Psychological Review, 97(1), 19-35. https://doi.org/10.1037/0033-295X. 97.1.19.

Chen, Y., \& Hoshower, L. B. (2003). Student evaluation of teaching effectiveness: An assessment of student perception and motivation. Assessment \& Evaluation in Higher Education, 28(1), 71-88. https://doi.org/10.1080/02602930301683.

Deci, E. L., Koestner, R., \& Ryan, R. M. (1999). A meta-analytic review of experiments examining the effects of extrinsic rewards on intrinsic motivation. Psychological Bulletin, 125(6), 627-668. https://doi.org/10.1037/0033-2909.125.6.627.

Desimone, L. M. (2009). Improving impact studies on teachers' professional development: Toward better conceptualizations and measures. Educational Researcher, 38(3), 181-199. https://doi.org/ 10.3102/0013189X08331140.

Ditton, H., \& Arnoldt, B. (2004). Wirksamkeit von Schülerfeedback zum Fachunterricht [Effectiveness of student feedback on subject teaching]. In J. Doll (Ed.), Bildungsqualität von Schule [Quality of education in schools] (pp. 152-170). Waxmann.

Elstad, E., Lejonberg, E., \& Christophersen, K. A. (2017). Student evaluation of high-school teaching: Which factors are associated with teachers' perception of the usefulness of being evaluated? Journal for Educational Research Online, 9(1), 99-117.

Enns, E., Rüegg, R., Schindler, B., \& Strahm, P. (2002). Lehren und Lernen im Tandem. Porträt eines partnerschaftlichen Fortbildungssystems [Teaching and learning in tandem: Portrait of a continuing education system based on partnership]. Zentralstelle für Lehrerinnen- und Lehrerfortbildung Kanton.

Finnegan, R. S. (2013). Linking teacher self-efficacy to teacher evaluations. Journal of CrossDisciplinary Perspectives in Education, 6(1), 18-25.

Ford, T. G., Urick, A., \& Wilson, A. S. (2018). Exploring the effect of supportive teacher evaluation experiences on US teachers' job satisfaction. Education Policy Analysis Archives, 26(59), 83-93. https://doi.org/10.14507/epaa.26.3559.

Gärtner, H. (2007). Unterrichtsmonitoring [Classroom monitoring]. Münster, Germany: Waxman.

Gärtner, H. (2013). Wirksamkeit von Schülerfeedback als Instrument der Selbstevaluation von Unterricht [Effectiveness of student feedback as a tool for self-evaluation of teaching]. In J. Hense, S. Rädiker, W. Böttcher, \& T. Widmer (Eds.), Forschung über Evaluation. Bedingungen, Prozesse und Wirkungen [Research on evaluation: Conditions, processes and effects] (pp. 107124). Waxmann.

Gates Foundation. (2012). Asking students about teaching: Student perception surveys and their implementation (Policy \& Practice Brief). Bill \& Melinda Gates Foundation. Retrieved from http://www.metproject.org/downloads/Asking_Students_Practitioner_Brief.pdf.

Guskey, T. R. (2002). Professional development and teacher change. Teachers and Teaching: Theory and Practice, 8(3/4), 381-391. https://doi.org/10.1080/135406002100000512. 
Harvey, L. (2002). The end of quality? Quality in higher education, 8(1), 5-22. https://doi.org/10. 1080/13538320220127416.

Hattie, J. (2009). Visible learning: A synthesis of over 800 meta-analyses relating to achievement. Routledge. https://doi.org/10.4324/9780203887332.

Hattie, J., \& Timperley, H. (2007). The power of feedback. Review of Educational Research, 77(1), 81-112. https://doi.org/10.3102/003465430298487.

Helmke, A. (2017). Unterrichtsqualität und Lehrerprofessionalität. Diagnose, Evaluation und Verbesserung des Unterrichts [Quality of teaching and teacher professionalism: Diagnosis, evaluation and improvement of teaching]. Klett-Kallmeyer.

Helmke, T., Helmke, A., Schrader, F.-W., Wagner, W., Nold, G., \& Schröder, K. (2008). Die Videostudie des Englischunterrichts [The video study of English teaching]. In DESI-Konsortium (Hrsg.), Unterricht und Kompetenzerwerb in Deutsch und Englisch. Ergebnisse der DESI-Studie [Teaching and competence acquisition in German and English: Results of the DESI study]. (pp. 345-363). Beltz.

Kember, D., Leung, D. Y., \& Kwan, K. (2002). Does the use of student feedback questionnaires improve the overall quality of teaching? Assessment \& Evaluation in Higher Education, 27(5), 411-425. https://doi.org/10.1080/0260293022000009294.

Kleeberg-Niepage, A. (2012). Zur Entstehung von Rechtsextremismus im Jugendalter-oder: Lässt sich richtiges politisches Denken lernen? [On the emergence of right-wing extremism in adolescence-Or: Can proper political thinking be learned]. Journal für Psychologie [Journal for Psychology], 20(2), 1-30.

Klusmann, U., Kunter, M., Trautwein, U., \& Baumert, J. (2006). Lehrerbelastung und Unterrichtsqualität aus der Perspektive von Lehrenden und Lernenden [Teacher workload and teaching quality from the perspective of teachers and students]. Zeitschrift für pädagogische Psychologie [Journal for Educational Psychology], 20(3), 161-173. https://doi.org/10.1024/1010-0652.20. 3.161.

Kruger, J., \& Dunning, D. (1999). Unskilled and unaware of it: How difficulties in recognizing one's own incompetence lead to inflated self-assessments. Journal of Personality and Social Psychology, 77(6), 1121-1134. https://doi.org/10.1037/0022-3514.77.6.1121.

Kunter, M., \& Voss, T. (2013). The model of instructional quality in COACTIV. In M. Kunter, J. Baumert, W. Blum, U. Klusmann, S. Krauss, \& M. Neubrand (Eds.), Cognitive activation in the mathematics classroom and professional competence of teachers (pp. 85-113). Springer. https:// doi.org/10.1007/978-1-4614-5149-5.

Luft, J., \& Ingham, H. (1955). The Johari window, a graphic model for interpersonal relations. University of California.

Marsh, H. W., \& Dunkin, M. J. (1992). Students' evaluations of university teaching: A multidimensional perspective. In J. C. Smart (Ed.), Higher education: Handbook of theory and research. Agathon Press.

Mayo, M., Kakarika, M., Pastor, J. C., \& Brutus, S. (2012). Aligning or inflating your leadership self-image? A longitudinal study of responses to peer feedback in MBA teams. Academy of Management Learning \& Education, 11(4), 631-652.

Milanowski, A. T., \& Heneman, H. G. (2001). Assessment of teacher reactions to a standards-based teacher evaluation system: A pilot study. Journal of Personnel Evaluation in Education, 15(3), 193-212. https://doi.org/10.1023/A:1012752725765.

Mortenson, B. P., \& Witt, J. C. (1998). The use of weekly performance feedback to increase teacher implementation of a prereferral academic intervention. School Psychology Review, 27(4), 613-627.

Newton, J. (2000). Feeding the Beast or Improving Quality? academics' perceptions of quality assurance and quality monitoring. Quality in Higher Education, 6(2), 153-163. https://doi.org/ $10.1080 / 713692740$.

Noell, G. H., Duhon, G. J., Gatti, S. L., \& Connell, J. E. (2002). Consultation, follow-up, and implementation of behavior management interventions in general education. School Psychology Review, 31, 217-234. 
Northcraft, G. B., Schmidt, A. M., \& Ashford, S. J. (2011). Feedback and the rationing of time and effort among competing tasks. Journal of Applied Psychology, 96(5), 1076-1086. https://doi.org/ $10.1037 / \mathrm{a} 0023221$.

Ory, J., \& Ryan, K. (2001). How do student ratings measure up to a new validity framework? New Directions for Institutional Research, 109, 27-44. https://doi.org/10.1002/ir.2.

Paseka, I., Schraz, M., \& Schrittesser, I. (2011). Professionstheoretische Grundlagen und thematische Annäherung [Professional theoretical foundations and thematic approach]. In ibid. (Eds.), Pädagogische Professionalität quer denken - umdenken - neu denken [Thinking pedagogical professionalism from a different angle-Rethinking-Thinking mew] (pp. 187-21). Facultas.

Penny, A. R., \& Coe, R. (2004). Effectiveness of consultation on student ratings feedback: A metaanalysis. Review of Educational Research, 74(2), 215-253. https://doi.org/10.3102/003465430 74002215.

Pritchard, R. D., Holling, H., Lammers, F., \& Clark, B. D. (2002). Improving organizational performance with the productivity measurement and enhancement system: An international collaboration. Nova Science.

Reh, S. (2004). Abschied von der Profession, von Professionalität oder vom Professionellen? [Farewell to the profession, to professionalism or the professional]. Zeitschrift für Pädagogik, $50(3), 358-372$.

Schön, D. A. (1987). Educating the Reflective Practitioner. Jossey-Bass.

Seidel, T., \& Shavelson, R. J. (2007). Teaching effectiveness research in the past decade: The role of theory and research design in disentangling meta-analysis results. Review of Educational Research, 77(4), 454-499. https://doi.org/10.3102/0034654307310317.

Skaalvik, E. M., \& Skaalvik, S. (2007). Dimensions of teacher self-efficacy and relations with strain factors, perceived collective teacher efficacy, and teacher burnout. Journal of Educational Psychology, 99(3), 611-625. https://doi.org/10.1037/0022-0663.99.3.611.

Spencer, K. J., \& Schmelkin, L. P. (2002). Student perspectives on teaching and its evaluation. Assessment \& Evaluation in Higher Education, 27(5), 397-409. https://doi.org/10.1080/026029 3022000009285.

Sproule, R. (2000). Student evaluation of teaching: Methodological critique. Education Policy Analysis Archives, 8(50), 125-142. https://doi.org/10.14507/epaa.v8n50.2000.

Sproule, R. (2002). The underdetermination of instructor performance by data from the student evaluation of teaching. Economics of Education Review, 21(3), 287-294. https://doi.org/10.1016/ S0272-7757(01)00025-5.

Staub, F. (2001). Fachspezifisch-pädagogisches Coaching: Theoriebezogene Unterrichtsentwicklung zur Förderung von Unterrichtsexpertise [Specialised pedagogical coaching: Theoretical teaching development to promote teaching expertise]. Beiträge zur Lehrerinnen-und Lehrerbildung, 19(2), 175-198.

Uttl, B., White, C. A., \& Gonzalez, D. W. (2017). Meta-analysis of faculty's teaching effectiveness: Student evaluation of teaching ratings and student learning are not related. Studies in Educational Evaluation, 54, 22-42. https://doi.org/10.1016/j.stueduc.2016.08.007.

Wang, H., Hall, N. C., \& Rahimi, S. (2015). Self-efficacy and causal attributions in teachers: Effects on burnout, job satisfaction, illness, and quitting intentions. Teaching and Teacher Education, 47, 120-130. https://doi.org/10.1016/j.tate.2014.12.005.

Wisniewski, B., Engl, M., \& Zierer, K. (2019). Mehr Demokratie wagen: Warum Schülerfeedback Schule demokratischer macht [Dare more democracy: Why student feedback makes schools more democratic]. SchulVerwaltung BY, 3, 68-72.

Wisniewski, B., \& Zierer, K. (2019). Visible Feedback-From Research to Reality. Kappa Delta Pi Record, 55, 66-71. https://doi.org/10.1080/00228958.2019.1580984.

Wisniewski, B., Zierer, K., Dresel, M., \& Daumiller, M. (2020a). Obtaining students' perceptions of instructional quality-Two-level structure and measurement invariance. Learning and Instruction, 66(2). https://doi.org/10.1016/j.learninstruc.2020.101303. 
Wisniewski, B., Zierer, K., \& Hattie, J. (2020b). The power of feedback revisited: A meta-analysis of educational feedback research. Frontiers in Psychology, 10, 3087. https://doi.org/10.3389/fpsyg. 2019.03087.

Zierer, K. (2015). Nicht nur Wissen und Können, sondern auch und vor allem Wollen und Werten. Das K3W-Modell im Zentrum pädagogischer Expertise [Not only knowledge and ability, but also and above all willingness and values. The $\mathrm{K} 3 \mathrm{~W}$ model at the centre of pedagogical expertise]. Pädagogische Rundschau [Pedagogical Review], 69(1), 91-98. https://doi.org/10.1163/258 90581-091-01-90000008.

Zierer, K., \& Wisniewski, B. (2018). Using Student Feedback for Successful Teaching. Routledge. https://doi.org/10.4324/9781351001960.

Benedikt Wisniewski is a school psychologist, former teacher, and teacher trainer. As a researcher and lecturer, he works at the University Augsburg (Germany). His research focuses on students' and teachers' perceptions of instructional quality and the validity of student feedback. In 2014, he co-founded FeedbackSchule, a German online platform for obtaining professional student feedback.

Klaus Zierer is a Professor of School Education at the University of Augsburg (Germany). He taught for five years in primary and secondary schools. In 2009 he was a Visiting Research Fellow at the Department of Education, University of Oxford (UK). He is currently an Associate Research Fellow of the ESRC Centre on Skills, Knowledge and Organisational Performance (SKOPE). His research interests include international aspects of school education, learning and teaching, teacher education, and professionalization.

Open Access This chapter is licensed under the terms of the Creative Commons Attribution 4.0 International License (http://creativecommons.org/licenses/by/4.0/), which permits use, sharing, adaptation, distribution and reproduction in any medium or format, as long as you give appropriate credit to the original author(s) and the source, provide a link to the Creative Commons license and indicate if changes were made.

The images or other third party material in this chapter are included in the chapter's Creative Commons license, unless indicated otherwise in a credit line to the material. If material is not included in the chapter's Creative Commons license and your intended use is not permitted by statutory regulation or exceeds the permitted use, you will need to obtain permission directly from the copyright holder. 